\title{
The fuzzy boundary between the roles of interpreter and mediator in the public services in Catalonia: Analysis of interviews and interpreter-mediated interactions in the health and educational context
}

\author{
Marta Arumí Ribas, Universitat Autònoma de Barcelona
}

\begin{abstract}
In Catalonia, there is great ambiguity regarding the terms employed to define the roles, profiles and scope of the individuals who act as intermediaries in the communication process in public services. The main confusion surrounds the terms of intercultural mediator and interpreter. This article aims to contribute to the current debate on the fuzzy boundary between these roles. We first describe the conceptions and beliefs, collected through semi-structured interviews, from healthcare staff, health service managers and interpreters about the different roles. Secondly, we analyse whether the evident confusion is also reflected in the educational context.

A widespread tendency to resort to intercultural mediators in the health and educational contexts is observed, despite the fact that they are in most cases performing the task of an interpreter. Even though it is possible for the same professional to carry out both roles, this article advocates establishing a clear differentiation between them, and stresses the importance of specialized training.
\end{abstract}

Keywords: Public Service interpreter; intercultural mediator; semi-structured interviews; interpreter-mediated interactions; role.

\section{Introduction: the co-existence of roles in Catalonia}

In Catalonia, and in Spain, communication between public services staff and users was not seen as a matter of great importance until recently, when hospitals, schools, local government offices and courtrooms have increasingly become little Towers of Babel. Initially, due to the pressing need of the situation, family, friends and volunteers, working through NGOs, acted as a bridge of communication between the authorities and the new arrivals. Nowadays, however, there are several co-existing professions aimed at facilitating communication between immigrants, who do not know the official languages, and public services staff. Catalonia is a clear example of how a country's immigration and language policies affect the provision of linguistic access to public services. Under what we can refer to as the "umbrella of professionals for mediated intercultural communication" there are translators and interpreters, public service interpreters, intercultural mediators, linguistic mediators, interlinguistic mediators, newcomer settlement agents, etc. The origin of their designations and their specific functions are not always clear. Undoubtedly, the confusion surrounding the different role perceptions can be attributed to the newness of the professions and the lack of clarity of the legislation that should regulate them.

As a result of the geographical location, trade relations, political and religious conflicts and economic growth of Catalonia and its surrounding areas, the region has received several waves 
of immigration, which peaked in 2004. These generated various demands that required a response. The Catalan government took its first actions in the late 1980s, and since then, there have been a number of four-year immigration plans. These plans have never provided a precise definition of the various professions, opting for vague definitions such as the term "communication services facilitators," which first appeared in the 2005-2008 Citizenship and Immigration Plan (Pla de Ciutadania I Immigració 2005-2008, 2005). In the judicial and police fields, on the other hand, the figure and intervention of the interpreter is unquestioned, and is reinforced by the implementation of Directive 2010/64/EU on the right to interpreting and translation in criminal proceedings.

In light of this situation, in this article we aim to describe the conceptions and beliefs of interpreters, healthcare staff and healthcare service managers about the roles of mediation and interpreting and also to analyse whether the confusion that is perceived in the roles can be observed in the simulations of mediated interactions in the educational context.

\section{Interpreting as mediation}

If we review academic discussions in recent years regarding the role of the interpreter, we find a continuum ranging from the notion of the interpreter as a neutral and invisible figure right through to intervention, including half-way positions which refer to the interpreter as an active participant, as a cultural broker or gatekeeper (Davidson, 2000). Traditionally, descriptive and normative studies on dialogic interpreting contributed to further the idea of the interpreter as a mere linguistic instrument (Beltran-Avery, 2001), whose role was confined to relaying the message (conduit model) without participating in the social interaction (Roy 2000). The conduit approach in interpreting predominated in early interpreting studies which focused rather exclusively on conference interpreting. The notions of neutrality and invisibility in the field of PSI were contested by studies which emphasised the interpreter's role in jointly constructing the interaction (Wadensjö 1998, Roy 2000), supporting the view of the interpreter as an active participant. The proliferation of research on the role of the interpreter revealed how the interpreter participates, inevitably, in jointly constructing communicative events and even influences how these events develop (Wadensjö 1998; Baraldi \& Gavioli 2007; Roy 2000; Davitti 2013).

In recent years, many articles have analysed the function of interpreting as a form of linguistic and cultural mediation (Baraldi \& Gavioli 2007; Davitti 2013) in line with Pöchhacker's affirmation that "every interpreter is a mediator (between languages and cultures), but not every mediator is an interpreter" (2008: 14). As Davitti points out (2013), mediation and interpreting had been studied in parallel. Linguistic analysis had focused on research on interpreting, while research on intercultural mediation had been focused on aspects such as the fostering of cultural acceptance, mutual co-operation and understanding, the empowerment of participants, etc., without taking into account that all these objectives are achieved and affected by language. In the same vein, Wadensjö (1998) emphasises that beyond simply relaying the parties' content, interpreting means co-ordinating interactions. She advocates research into the interactional dimension of interpreting through the combination of the linguistic and cultural aspects of mediation, which affect the accuracy of the renditions as well as facilitating communication. In relation to the visibility of the interpreter, Angelelli (2004) goes even further in referring to a model of visibility featuring an interpreter who is not only visible from a linguistic point of view, but also in relation to the social and cultural factors that enable him or her to jointly construct a definition of reality together with the other participants in the interaction. 
In 2008, Pöchhacker drew attention to the confusion between the concept of mediation in the sense of conflict and the concept of mediation in the communicative sense, i.e. the participation of the interpreter in co-ordinating the interaction. According to Pöchhacker, it is important to differentiate between the three analytical dimensions of mediation: 1) linguistic and cultural mediation, including intercultural mediation, which would be synonymous with interpreting; 2) cognitive mediation, which would account for the subjectivity of interpreters, and 3) contractual or conflict mediation, which would entail facilitation of communication, conflict management and power relationships. Pöchhacker (2008) points to the fear, in countries such as Italy, of proliferation of the figure of the intercultural mediator who must not only carry out the role of interpreting between communities, but must also manage the cultural gaps that may arise in public service situations. He also stresses the difficulty involved in dissociating the role of establishing positive intercultural relations from that of mediating between languages.

In Spain, Giménez was the first scholar to focus on and define intercultural mediation $(1997: 129)$ :

\footnotetext{
"Intercultural mediation -or social mediation in multiethnic or multicultural contexts- is understood to be an intervention by a third party, specifically in significantly multicultural social settings, which seeks to secure recognition of the other and the rapprochement between the parties, communication and mutual understanding, the learning and development of co-existence, the regulation of conflict and institutional adaptation between social and institutional actors who have ethnocultural differences"1
}

From this perspective, intercultural mediation is regarded as an activity which is aimed at promoting and facilitating relationships between culturally diverse groups (Hernandez, 2006). According to Giménez (1997), the new migratory flows and social, economic and technological globalisation, among other factors, have led to highly multicultural social situations in which the objective is to achieve recognition of the other. Giménez describes such situations as ones in which, for whatever reason, the sociocultural distinctiveness of the parties becomes significant and central, or at least particularly influential. He identifies four specific features of intercultural mediation: (1) the nature of the ethnocultural differentiation in the relationship between the parties, (2) the effect of ethnocultural differentiation in that relationship, (3) the importance of the mediator's own cultural knowledge, and (4) multiculturalism as an objective. As Antonin (2009) states, intercultural mediation is conceived not only as a process but also as a resource (Bermudez et al. 2002) to be made available to individuals and groups of different cultures, in order to build bridges of understanding that facilitate communication, relationships and, ultimately, help the different groups to integrate. Pérez Crespo (2005:256) distinguishes four areas of mediator intervention; (1) the access of the immigrant population to resources and the adaptation of existing services to the new population group, (2) the support to mediators in their work with the foreign population, (3) to foster and promote citizen participation and (4) to actively liaise to achieve intercultural harmony between all the parties. In short, the intercultural mediator is configured as a professional who is able to manage cultural diversity, facilitating, above all, communication, fostering social cohesion and promoting the autonomy and social integration of minorities (Bermudez et al., 2002).

Based on these definitions, a clear difference can be observed between the tasks assumed by the intercultural mediator and by the interpreter in public services. The latter's ultimate objective is to decode messages from a source that has a different language (and therefore a different culture) from the receiver and to act as a vehicle for communication, transferring verbal messages from one language to another so that the parties can communicate autonomously and independently.

\footnotetext{
${ }^{1}$ The translation of quotes and interview extracts is ours.
} 


\section{Analysis of interviews and interactions in the health and educational contexts}

The extracts of interviews with interpreters, staff and managers in the healthcare context set out in the following sections give an overview of their vision of the figure and roles of mediators and interpreters in the Catalan health system. Subsequently, the analysis of simulations of interactions in the educational context contributes to the description of mediators' activities and techniques and the identification of patterns that reveal how the interpreting and mediation functions are intertwined.

\subsection{Analysis of semi-structured interviews}

We carried out 50 semi-structured interviews (15 with interpreters, 9 with health service managers and 26 with health service staff) in different hospitals in the city of Barcelona. We followed a script with different questions that was applied flexibly ${ }^{2}$. We will now examine how each of these groups addresses the issue of the roles of interpreting versus mediation and the overlap between them.

Intercultural mediators, working in Darija Arabic, Romanian, Chinese, Urdu, English and French, in addition to Spanish and Catalan, describe themselves as a bridge facilitating communication, especially in relation to cultural references:

1. When you're in Ramadan, you can't even take medication, can you? Because you have to fast. Well, one of their roles is to say, to explain to the professional that they're in Ramadan, because obviously the professional doesn't know whether it's the month of Ramadan or not the month of Ramadan, to tell him or her that they can't take any medication, and see if, instead of being given tablets every eight hours, they can be given every twelve. At the same time they remind the user that during Ramadan people who are ill are allowed to take medication.

2. For example, where a great deal of mediation has also been carried out, it's on internal medicine, on the issue of respiratory diseases such as tuberculosis, explaining the fundamental and essential facts to avoid infecting someone, one of their family, because everyone has to do a follow-up? don't they?

According to health services staff, intercultural mediation represents an added value to interpreting since intercultural mediators not only interpret the linguistic code but also the cultural code.

3. But cultural mediators are ... I... in fact, I expect much more from them than a translation. In my practice, I have patients who speak English, French. And I can speak English and French, I don't need translators. I don't need them. But often I do need interpreters. In fact, I would also need them for patients who are from South America, who speak the same language. So the role of mediators, and not interpreters, is a complex one, to act as a bridge, they don't attract attention away from the doctor, or attract attention at all, on the contrary, they act as intermediaries, make a bridge. They are the link between the health system and patient. Facilitating, helping towards understanding... and then sometimes translating. But no, that's the essential thing.

\footnotetext{
${ }^{2}$ This study is part of the Phd dissertation of Noelia Burdeus Domingo (2015), entitled Public Service Interpreting in a Healthcare Setting: A comparative study of the cities of Barcelona and Montreal. Phd dissertation. Department of Translation and Interpreting and East Asian Studies. Universitat Autònoma de Barcelona.
} 
Similarly, the mediators interviewed stressed that, although intercultural mediators are associated with roles related to community work, such as accompanying, widening the network of associations, etc., these are not the main focus of their work. In fact, they highlight that their job is to interpret between people of two different cultures where cultural decoding is required.

The interviews also reveal the existence of the figure of the community worker who has the ability to impart certain healthcare messages, therefore taking a role beyond that of a mere communicator. One healthcare service manager describes it like this:

4. The figure of the healthcare worker existed long before intercultural mediation. For the large part, they worked in what would be primary health care, and they mainly did community health work. They worked with groups. They were people who represented a particular community, who had a particular training, who were familiar with our healthcare system; they were familiar with the concept of health of their community of origin, right? and they worked on certain issues to help to change behaviour.

According to respondents, community health workers act as a bridge between the health services and the community with which they work, and their role is broader than that of the intercultural mediator. One health service member of staff describes it like this:

5. It's a broader role (...) It is not so much acting as a bridge, but you have more skills and abilities, (...) to work yourself directly with the community, not only with a person from the community acting as a bridge but to work directly with the community, for example with a group of people on the prevention of tuberculosis, or HIV or sexually transmitted diseases.

It should be noted that healthcare staff who work with community healthcare workers champion this profession, defending it as a model to be implemented in other healthcare centres on the basis of the added roles compared with the intercultural mediator.

6. Outside the centre, that's what sets the community healthcare worker apart from, say, a translator, interpreter or mediator isn't it? It's the work outside, where you're working within the community, with those that need you, especially in community healthcare prevention programmes.

Both healthcare service managers and staff as well as mediators agree that the following roles are characteristic of communication professionals in public services: 1) Interpreting; 2) Mediation if there is any cultural misunderstanding; 3) Accompanying (inside or outside the healthcare system); 4) Cultural orientation within the healthcare system (and outside it) and 5) Translation and adaptation of written medical material. In addition to these roles, both healthcare staff and PSI professionals include that of diffusion of the services. Similarly, the managers mention that mediators are also associated with other tasks that go beyond their job description such as customised user support.

\subsection{Analysis of interactions in the educational context}

The data analysed in this section are part of a broader study aimed at studying the strategic behaviour of mediators in public services in the socio-educational context, focusing on the 
Chinese-Spanish and Darija Arabic-Spanish language pairs ${ }^{3}$. The data was collected by recording simulations of interpreting situations in the socio-educational context. The data were supplemented with an initial questionnaire and a retrospective interview with the mediators taking part in the experiment. For the data collection, 10 professionals were selected, 5 with the Chinese-Spanish/Catalan pair and 5 with Darija Arabic-Spanish/Catalan pair, the majority of whom regarded themselves as professional mediators (only one of the professionals selected, who had the Chinese-Spanish language pair, stated that she regarded herself as a interpreter). The Chinese mediators, all of whom were women, had at least 2 years experience in the public services context. Based on the information from the initial questionnaires, two of them were born in Catalonia, one in France (of Spanish parents) and two in China. Their mother tongues were Catalan, Spanish and Chinese, respectively. While two of them had degrees in translation and interpreting, none had received any specific training in PSI, although three had taken courses in intercultural mediation. Of the Darija Arabic mediators, 4 were women and only one was a man. They were all from Morocco, and had between 9 and 16 years of experience in the field of intercultural mediation. Only one had PSI training. In terms of languages, 3 of the mediators had Darija (Moroccan) Arabic as their mother tongue, and two, in addition to Darija, had Tarifit or Amazigh Rif.

Although the simulation was based on a script developed by the research team that was to be followed to ensure that the different interactions were similar, this could be adapted to ensure that the interaction was coherent. A static camera was focused directly on the interpreter but it also showed the various participants in profile. In this way the recording technicians were not required to be physically present during the simulations, to avoid any distraction.

Each of the mediators participated in simulations of the three prepared scripts. The first simulation (in a secondary school) took an average of 24 minutes; the second (in a Municipal Education Office) took an average of 15 minutes and the third (in a Social Services Office) an average of 18 minutes.

At the end of the simulations, retrospective interviews were conducted. One of the researchers, who had been taking notes on the development of the interaction, conducted the interviews. They were also recorded with the video camera to facilitate their subsequent transcription and analysis. The average length of the interviews was 40 minutes.

In the following subsections, based on the analysis of various extracts, we observe the mediators' intervention. The analysis is divided into five broad categories: management of cultural references; interaction management; power management; empathy and emotion management and use of professional techniques.

\section{Management of cultural references}

In general, the mediators tend, through an expanded rendition (Wadensjö 1998), to explain the cultural references. Most of the time they do so without either party being aware that an explanation is being added. In the following excerpt ${ }^{5}$, taken from the simulation recreating a school meeting between a tutor and a Chinese mother, we pick up the moment when the tutor tells the mother that her son has failed his Spanish and Catalan language subjects but nevertheless, tells her that he will be able to pass them.

${ }^{3}$ Project (FFI2001-23905) "Problems and strategies in public service translation and interpreting in the socioeducational setting" funded by the Spanish Ministry of Education and Science and conducted by the MIRAS research group [2014SGR545] (http: //grupsderecerca.uab.cat/miras). 
Extract $1 . \mathrm{T}=$ tutor; $\mathrm{M} 1=$ mediator $1 ; \mathrm{M} 2=$ mediator 2

T:

A veure... ara, eh... les que té suspeses, són amb quatres, eh?; que són el castellà i el català, bàsicament, són tres i mig - quatre. $\mathrm{O}$ sigui que arribarà a aprovar.

Let's see now ... right ... the ones he failed, that he failed with a four, they are Spanish and Catalan, basically, a three and a half-four. So he'll be able to pass them.

M 1: 没及格的课程就是有两个都是四分多, 四分多就是西班牙语根加泰兰与是没及格, 但 是不是很差, 还可以, 老师, 班主任, 老师说他可以毕业, 可以及格这两个课程。 Let's see (.) the ones he hasn't passed are Spanish and Catalan, but the marks aren't very low, a three and a half-four, five is the cut-off mark, you pass, you make the grade.

M 2: 她说现在呢他还没有过那些课程就是西班牙语跟加泰罗尼亚语, 还是语言那方面嘛, 就是他的分就是三点五四分，因为在西班牙满分不是一百分，在这里是十分嘛，他得到是 三点五、四: :

She says that the ones he hasn't passed are Spanish and Catalan, the language subjects, where he got a three and a half-four; because in Spain the marks aren't out of 100, here it's out of ten, and he got a three and a half-four:::

${ }^{5}$ In each of the excerpts the author leaves the original intervention in Spanish or Catalan and provides a translation into English (in italics).

We have included the solution of two different mediators (M1 and M2). M1 adds a cultural explanation using the expression "four, five is the cut-off mark, you pass, you make the grade", in addition to adding a value judgment "but the marks aren't very low", aimed at reassuring the mother. M2 chooses to add a more direct cultural explanation, based on the grading system "in Spain the marks aren't out of 100, here it's out of ten." In both cases, the expanded rendition strategy is used to put the cultural reference into context. In the retrospective interviews, both mediators state that, because the Chinese grading system is very different from the Spanish one, they feel they need to include cultural assistance to help the mothers to get to know the new educational system.

\section{Managing the interaction}

We identified three actions taken by mediators to manage the three-way exchange:

- Asking their own questions

- Simplifying the information

- Direct decision-making

\section{Asking their own questions}

In some cases, the mediators ask their own questions in order to clarify, disambiguate, or confirm confusing information. However, these questions usually slow down the interaction. Moreover, if this is not followed up with a strategy of transparency, i.e. if the mediator does not immediately explain to the other party what has been asked, this tends to lead to a monolingual dialogue with one of the primary partners from which the third participant is excluded. As noted by Bolden (2000), at that point there is no longer an interpreted conversation but two parallel and intertwined conversations, one between the user and the interpreter and another between the provider and the interpreter. In the following example, taken from the simulation which 
recreates a meeting in a Social Services Office, in turn 07 the user gives an incoherent answer to the question of whether she has gone to the police to report her husband.

Extract 2. Social worker=SW; Mediator 1=M1; Mediator 3=M3; User=U

01.SW: Lo primero de todo le tenemos que hacer unas preguntas sobre su familia y su vivienda. ¿Está casada?

First, we are going to start by asking you some questions about your family and your home. Are you married?

02. M1：我们先就是开始问一下 ehm::: 你的家庭情况还有你的::: 在家里，你们家人。然后她 问一下你::: 你结婚了没有?

First, we are going to start asking a bit about, um::: your family and also your::: at home, about your family. So she is asking if you::: are you married?

03. $\mathrm{U}$ : 对, 但是两个半月前我丈夫离家出走了/跑了, 不知道他在哪儿。没有来电话, 也不给 我们生活费。

Yes, but my husband left home two and a half months ago and I don't know where he is. He doesn't phone and he doesn't give us any money to live off.

04. M1. Ehm::: está casada, pero lleva dos meses y medio que no tiene noticias de su marido, que se ha ido y bueno, está muy preocupada. No no sabe::: qué ha pasado (.) está::: (.) sola, sin::: (.) sin::: (.) bueno

Mmm::. she's married, but she hasn't heard from her husband in two and a half months, he's left and well, she's very worried. She doesn't know::. what's happened (.) she's.:. (.) alone, without:.: (.) without:.: (.) well

05. SW: Mujer, no se preocupe... ¿Ha denunciado en la policía que su marido se ha ido? Don't worry love. Have you been to the police to report that your husband has left you?

06. M1: 这个你去警察高这情况吗?

Yes, have you been to the police to report your situation?

07. U: 从圣诞节前就没见到他。 I haven't seen him since before Christmas

08. M1: Eh 她问的就是你去找这个警察? [告这个情况 No, they are asking if you've been to the police...

09. M3: 那你没有去警察那边报案你老公失去了吗?

So you haven't been to the police to report it?

After the incoherent answer of the user, in turns 08 and 09, mediators 1 and 3 make personal interventions and start up a dialogue with the user to try to redirect the question and obtain the information requested by the social worker. However, by not indicating that they are starting a dialogue to clarify the meaning of the question, there is no strategy of transparency towards the social worker.

In other cases, the mediators use questions not because there is a misunderstanding but to be able to gain further information and provide a fuller rendition to the user. In the following excerpt, the mediator decides to ask the tutor a direct question ("Why? What does it depend on? Whether there are any places in the area they live in?), which sparked a dialogue with the tutor, and the information obtained was picked up in turn 04.

Extract 3. $\mathrm{T}=$ tutor; $\mathrm{M}=$ mediator.

01. T: Lo intentaremos. De todos modos, esto no somos nosotros los que decidimos. Tomo nota de lo que me dice y así la Comisión de Escolarización podrá tomar una decisión al respecto. No le puedo garantizar que pongan al niño en primero de primaria, pero lo intentaremos.

We'll try. In any event, we're not the ones who take the decision. I've made a note of what you say, so the School Commission can take the decision. I can't guarantee they'll place your son in the first year of primary, but we'll try.

02. M: Por qué... ¿de qué depende? ¿A ver si hay plazas por la zona donde vive? 
Why? What does it depend on? Whether there are any places in the area they live in? T: Exacto.

Exactly.

03. $\mathrm{M}$ : 阿姨, 您看, 现在学校的 $(\mathrm{xxx})$ 都有, 已经都三月了, 然后这个也不是说她能决 定的他报到一年级就一年级的，在西班牙这边他们都有什么东西要通过那个教育总局 嘛，对不对，然后去看一下你住家旁边还有没有学校。就是有空位让孩子进去，好不 好?

So that doesn't mean because she wants to register him in the first year that he'll go into the first year. In Spain, here, when there is something like this it has to be decided by the general education office, right? Then they check whether there are any schools near his house, that is if there are any free places for the boy, okay?

\section{Simplification of information}

In the following extract from the same meeting with the mother and the tutor, the interpreter decides to omit the entire first part of the message of the tutor and concentrate on the second part of the idea, which provokes a reaction from the mother. In Davidson (2000)'s terminology the mediator is acting as gatekeeper, with the aim of selecting only the information that, in her view, is more closely related to the subject under discussion.

Extract 4. $\mathrm{T}=$ tutor; $\mathrm{M}=$ mediator

T: Sí, perquè a més a més, així, després de dos anys ja tindrà un títol que li permetrà treballar. De totes maneres, el seu fill a vegades diu que li agradaria fer batxillerat.

Yes, because moreover, that way, after two years he'd have a qualification and would be able to work. However, your son sometimes says that he'd like to take baccalaureate (the final secondary school years in which pupils prepare for university entrance exams).

$\mathrm{M}$ :反正有时候你孩子已经谈过了跟老师说他希望能学习高中。

However, sometimes your son has said, has told the teacher he would like to be able to study baccalaureate.

This is a reduced rendition, because the mediator has omitted all of the first idea that after two years of study the pupil will obtain a qualification enabling him to work. In the mediator's retrospective interview, she states that she consciously used this strategy, in order to avoid overwhelming the user with too much information and confusing her. However, it is true that the subject under discussion at this point of the interaction clearly revolved around the option of the pupil studying baccalaureate, and that the idea of the two-year qualification could be considered secondary.

\section{Direct decision-making}

In the following extract from the same simulation, the tutor explains that in class they have been working with a handbook, to be used as a guide for the pupils finishing the fourth year of secondary school and the second year of baccalaureate with regard to different baccalaureate subject options, cut-off marks for admission to training courses and degrees, where to study, etc. The tutor, addressing the interpreter, asks if she wants her to go and get one. We detail below the reactions of four of the mediators to this same situation.

Extract 5. Tutor=T; Mediator 1=M1; Mediator 2=M2; Mediator 3=M3; Mediator 5=M5.

$\mathrm{T}$ : Voleu que en vagi a buscar un?

Do you want me to go and get one?

M1: Sí, d'acord. 
Yes, okay.

M1:一个纸头, 在纸头上有些他的喜欢的职业之类。那些。她现在会拿那个单子让你看。因 为可能有一点复杂。

Now she has gone to get one of those sheets to show you. Because maybe it's a bit complicated.

$\mathrm{T}$ : Voleu que en vagi a buscar un?

Do you want me to go and get one?

M2: 如果你要的话她可以马上去把本校的学习各种各样的学习目录教给你。

If you want, she can go right now to get a programme of the different types of courses that can be studied at this school to show you.

$\mathrm{T}$ : Voleu que en vagi a buscar un?

Do you want me to go and get one?

M3: Uh-huh (the interpreter nods to indicate that she wants her to go and get one).

M3: 过来给你看一看一件事情。

When she comes back she'll show you something.

$\mathrm{T}$ : Voleu que en vagi a buscar un?

Do you want me to go and get one?

M5: Sí, si us plau, a mi també m'anirà bé.

Yes, yes please, it'll be useful for me too.

M5:她要去拿一个本子。等一下。

Just a minute, she's gone to get a handbook.

Only M2 relays the question to the mother and gives her space to answer. In the other cases, the mediators felt the question was addressed to them and they decide to answer it directly. Although they communicate the exchange with the tutor to the mother straight away, involving her in what is happening, they are communicating to her decisions that have already been taken.

\section{Power management}

The issue of management of power and asymmetry as one of the roles adopted by the interpreter has been widely discussed in the literature (Pöllabauer, 2004). In the following extract, in turn 07 and through a direct question, the interpreter decides to invite the mother to speak again, so that she can give more information.

Extract 6. $\mathrm{T}=$ tutor; $\mathrm{M}=$ mediator; $\mathrm{Mo}=$ mother

01. T: Això vol dir que li podrem donar el graduat d' ESO, eh?, a part de perquè altres aspectes de maduració personal, de desenvolupament de personalitat, és a dir, tot això també ho té força bé, és un nen molt educat, sempre ha anat molt millor dintre la classe aquest any, ha fet un esforç per no estar aïllat, està molt més integrat; té alumnes al costat que l'ajuden o ell ajuda, eh= $\mathrm{O}$ sigui que en aquest aspecte estem molt contents de l'evolució del nen.

That means we can give him the ESO (Compulsory Secondary Education Graduate)

you see? In addition to other aspects of personal maturity or development of personality, which is also all pretty good, he is a very polite boy, and has always been much better within the class this year, has made an effort to not get left out, and is much more integrated, he has pupils next to him who help him or whom he helps, huh? So in this respect we are very happy with his progress.

02. M: 但是他们对你们的孩子学习水平特别满意啊, 除了那个西语以外的, 没考上的问题 啊其他的都完全好他::: 对他态度很成熟啊 eh::: 所以他一定会考上。=

But they are especially pleased with your son's work at school, apart from Spanish, and the problem of not having passed, as in everything else he's doing very well. He::. yes, he's got a very mature attitude::: so he will certainly be able to pass

03. Mo: 是啊, 在家里也一样。

04. M: Sí, en casa también. 
Yes, at home too.

05. M: 真的吗? 在家里他怎么样啊?

Oh really? What is he like at home?

In addition, we can see the mediator modifying the public service representative's register, more often than not simplifying and lowering it. She also adjusts the tone of her communication to the situation. On several occasions, she softens or neutralises it, acting as a kind of filter. In the example below, we find a strategy to simplify the register by simplifying the terminology. Here, the concept of "medical card" becomes "doctor's card".

Extract 7. SW=social worker; $\mathrm{M}=$ mediator

SW: Bueno, por hoy ya vale. Que le estamos dando demasiada información y la estamos confundiendo con tantas cosas. Mira, va a quedar con la intérprete por lo del abogado de oficio y tiene que dejarme los pasaportes, los permisos de residencia, las tarjetas sanitarias y la denuncia, yo lo fotocopio todo y se lo pongo en su historial.

Well, that's enough for today. We are giving her too much information and will confuse her with so many things. Listen, you'll meet the interpreter for the legal aid lawyer and you need to give me your passports, residence permits, medical cards and police report, I'll photocopy everything and put it in your file.

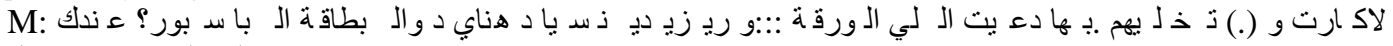

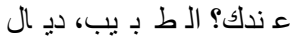

Do you have a passport? And the residence permit and::: the police report sheet. Give them to me (.) and the doctor's card, do you have that?

In the interviews, all the mediators state that, when the service providers make remarks to them that they immediately ask them not to interpret, they do as requested. We can see in the following extract from the interview with mediator 2 that, although she wishes to advocate neutrality and show herself as impartial, she ends up admitting that, if requested, she doesn't relay some messages.

Mediator 2: Sí, hi ha coses que sé que potser no cal arribar en ella, el missatge. Llavors ja no... no ho transmeto. Si hi ha coses que ella m'explica, i tal, i jo trobo que ella necessita saber-ho, això ja depèn de cadascú, no, una mica, del que pensa i tal, la manera de tractar... Jo intento ser sempre neutra, per la figura que som, i tal, perquè no som ni d'un costat ni de l'altre. Però sí, sí, si hi ha missatges que jo trobo que no cal, no ho transmeto.

Yes, there are things where I know the message perhaps doesn't need to get to her. So I don't... pass them on. If there are things she tells me, and so on, that I feel she needs to know, then it's your call a bit isn't it, it depends on what you think, the way you deal with people... I always try to be neutral, because of the role we have, and so on, because we don't take either side. But, yes, if there are messages I find I don't need to pass on, I don't. 


\section{Empathy and managing emotions}

The mediators have a very evident tendency to show empathy or even concern for the user, either by using interjections (ah!, oh!), by using non-verbal language, or explicitly, by using phrases such as "don't worry." In the same vein, they also use discourse markers (isn't that right?, isn't it?, okay?) to gain the user's co-operation or trust.

One of the Chinese mediators explained in the retrospective interview that it is very common in Chinese culture to use terms of designation of kinship with people outside the family in order to establish a bond with them and show respect. Specifically, she cites her use of the term ayi (阿姨), which literally means “paternal aunt" but is often used to address older women to signify both respect and closeness at the same time. She stresses the importance of creating closeness to users and increasing their engagement.

In the following extract, notice how the interpreter adds to the information by telling the mother "that's nothing to worry about" as a strategy to gain her confidence:

Extract 8. Tutor $=\mathrm{T}$; Mediator $=\mathrm{M}$

T:

A més a més, si... és que si hi ha una cosa que aquí no la fan per exemple, no? seria una llàstima que no la fes, i tot això només per un transport, vol dir, sobre tot amb tren un pot anar d'una ciutat a l'altra sense problema...

Besides, if... if for example there's anything they don't do here... it would be a shame for you not to do it, just because of the transport I mean, especially when on the train you can get from one city to the other with no problem...

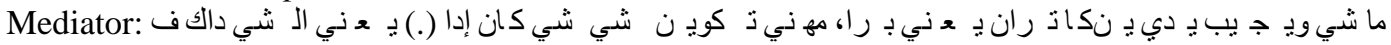

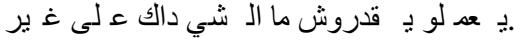

She says that you don't need, you don't need to worry about that, that is, if there are any training courses elsewhere, you've got the train to go back and forth and you don't need to rule it out it because of that.

In the interactions in Darija, terms such as "dear" or "sister" are frequently used to strengthen the closeness of the bond:

Extract 9.

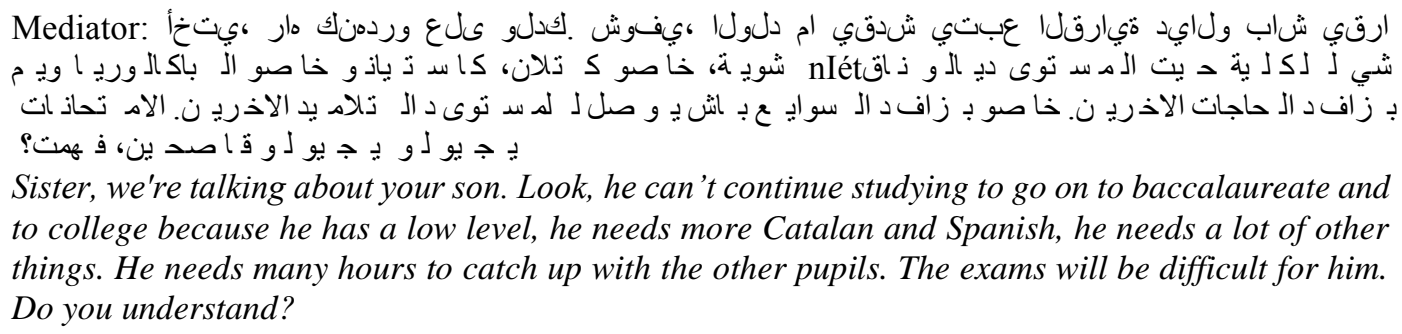

\section{Use of professional techniques}

It is striking how little use mediators make of interpreting techniques, in the form of note-taking or the rearrangement and restructuring of information. However, bearing in mind that only 2 of the mediators in the sample stated they had PSI training, it is not surprising that, in dealing with long passages of speech, lists, names or figures, they do not automatically take notes. Instead, they resort to strategies that slow down the flow of communication, such as the tendency to ask 
the speaker to stop and the breaking-down of lengthy ideas into several interventions or the use of questions to be sure that the information has been made clear to them.

In the following extract from the interview, mediator 1 explains that she never takes consecutive notes and what she does is stop the speaker when she sees that they are getting into a long passage of speech:

\footnotetext{
Mediator 1: Però no com a consecutiva, no apunto. No, no, no, mai, mai, mai. Per això pregunto. Quan es comença a allargar la cosa, potser no dic para sisplau, bueno, a vegades sí, però sí que faig un gest per aturar a la persona que parla.

But no, in consecutive I don't take notes. No, no, no, never, never, never. That's why I ask questions. When it starts to get long, I might not say please stop, well I do sometimes, but I make a sign for the person to stop talking.
}

\begin{abstract}
Mediator 5: M'ho he apuntat perquè tenia temps, perquè si no, no. Normalment només apunto a partir de quatre o cinc idees, començo a apuntar o si després veig que no me'n recordo d'algo, ho torno a preguntar.

I made a note because I had time, otherwise I don't. Normally I only take notes after four or five ideas, I start taking notes then or if I see later that I don't remember something, I ask again.
\end{abstract}

Moreover, nor do the mediators apply the techniques which would show the use of professional standards. For example, in general, none of them introduces herself at the beginning of the interactions or takes the initiative to agree on the management of turn-taking. Only Chinese mediator 5 asked to speak to the user beforehand. Nor do they show any preference or make any requests in relation to the seating arrangement in the room. Having said this, it is true that working with simulations in a room where a camera was already set up, did not invite requests for a change in the way the room was arranged.

\title{
4. Discussion
}

In this study, we have analysed the perceptions and beliefs of those taking part in mediated interactions in the public services regarding the roles of mediator and interpreter. We also study examples of interactions in which the role played by the professionals was observed. Both of these analyses support the ambiguity that was our initial premise. Firstly, it is surprising that the healthcare staff interviewed perceived that intercultural mediation adds value to interpreting, on the basis that the intercultural mediators include an interpretation of the cultural code in addition to the linguistic code. Here we find interpreting being erroneously equated to being literal, and, by solely and exclusively relaying the words, being likely to leave out the cultural content of the messages. As a result there is also the erroneous but widespread belief, that any bilingual person can successfully carry out the task of multilingual communication. There is a clear difference between being bilingual and being able to interpret professionally and accurately (Roberts, 1997). This was demonstrated in research in the Intercultural Mediation Services in Belgium (Verrept, 2004) which revealed that being bilingual did not automatically qualify mediators for professional interpreting.

Similarly, the intercultural mediators state that their everyday work focuses primarily on interpreting between people of two different cultures where cultural decoding is required. If the mediators take on the role of interpreter, a clear gap in their training in interpreting techniques is highlighted. This is particularly noticeable in the use of personal interventions when they are not required and in their frequent lack of transparency in communication. Cohen-Emerique (1997), in their research conducted in France and Switzerland, also found that the mediators themselves admitted they mainly assume interpreting roles. The institutional partenaires, 
especially in the hospital context, tended to limit mediators exclusively to this role. Fayman (2000) also makes reference to this issue:

\begin{abstract}
"Le médiateur est plus qu'un traducteur et lorsqu'on le limite à cette fonction ou s'il s'y réduit luimême. c'est sans doute le signe d'une maturité moindre dans sa conception ", c'est oublier qu'il crée des liens, des espaces de transition, qu'il pose des passerelles et rapproche les points de vue entre les acteurs sociaux et les migrants. Mais, parallèlement, le médiateur, est moins qu'un traducteur, car il n'est pas formé à cette discipline qui exige une très bonne connaissance des deux langues et des valeurs qu'elles sous-tendent. D'où la nécessité, dès les premières demandes, de bien mentionner la différence entre le rôle de médiatrice et celui de traductrice interprète"
\end{abstract}

Both the health service managers and staff, and mediators, agree on the five roles of communication professionals in the healthcare field: Interpreting; Mediation in the event of possible cultural misunderstanding; Support; Cultural guidance through the healthcare system (and outside it); Translating and adapting written medical material. We note how the first role (interpreting) and the last (translating) relate to the profession of the interpreter and the remaining three (mediation, support and guidance) to the profession of the mediator. In the interviews, a third profession is also mentioned, the health worker or community health worker, who is directly involved in this area of ill-defined boundaries. Very often scholars do not distinguish between health workers and intercultural mediators in healthcare or they use their designations and profiles as synonymous concepts. However, there are primary care centres in the city of Barcelona which have chosen to work only with community health workers.

In relation to the analysis of mediated interactions, professionals make widespread use of their own strategies from conflict mediation (active listening, advocacy, personal interventions, etc.). When there is no explicit need for intervention, the implementation of these strategies means that an opportunity is lost for direct interaction and for respecting the agency of users, since the professionals are taking the decisions. In most situations, this intervention is not necessary, given that there is no apparent misunderstanding. The summarising strategy used is also unnecessary, and violates the principle of accuracy and faithfulness to the original. Even though it is employed with the good intention of not overwhelming and simplifying, the summarising used by the mediators we have studied does not allow users to access all the information that is being shared in the interaction.

With regard to cultural references, we note the frequent and successful strategy of giving explanations, usually by seeking an equivalent (when one is available) in the culture of origin. The strategy of seeking empathy is very common in both Chinese and Darija interpreters. Although this would merit a separate study, from the examples analysed we can see how the closeness is usually sought in relation to the figure of the user, with whom the mediators try to establish a climate of trust through non-verbal language, speech markers and terminology denoting kinship, affection and familiarity.

Furthermore, mediators make little use of consecutive interpreting strategies (note-taking, management of turn-taking, memorising techniques, or restructuring of information, etc.) and of techniques related to different types of professional standards (initial introductions, definition of the role of the interpreter, etc.) that would help a smoother interaction, but, above all, give greater transparency. Both PSI and intercultural mediation are differentiated practices that aim to empower the user, i.e. put him or her on an equal footing. To truly achieve this, the user must be able to receive the same information as if he or she were able to communicate directly with the provider, in order to be able to make decisions, and to ask questions if in doubt.

\title{
5. Conclusions
}


In Catalonia, we can see a clear trend in the health and education contexts to opt for intercultural mediators rather than professional interpreters, on the basis that they have greater expertise in managing intercultural relationships and conflicts (Lizana, 2012). Unlike most Western countries that have a much longer history of multiculturalism (Australia, Canada, US, UK, Sweden, etc.), countries such as Spain or Italy have opted for a model in which the role of establishing positive intercultural relations between parties is given priority over the role of mediation between languages and cultures. To offer effective solutions ensuring successful communication, the diversity of needs must be recognised, and the right solution applied to cover each need. To underestimate the importance of interpreting as a specific professional technique, that has a particular contribution to make to the iterative communication process, and replace it with mediation, is, in our view, a mistake that can lead to lack of communication.

Both the mediator and the interpreter use their linguistic and cultural knowledge to achieve the overall aim of facilitating communication between people of different origins. However, each of the professions uses this knowledge to achieve different specific objectives. The interpreter seeks to play a vehicular role, a non-obstructive role that enables the two parties to communicate. In light of the language barriers, the interpreter becomes the voice of each of the parties in the language of its speaker so that they can communicate independently and autonomously. The mediator, on the other hand, has the task of supporting the parties' interaction when there is conflict, taking action in creative and generative intervention. To resolve cultural misunderstandings (i.e. explicit or implicit conflicts), the mediator interacts with each of the parties and uses his or her own voice to bring about a change that permits individuals or groups, who, without the action of the mediator are naturally distanced by to their cultural differences, to draw together.

To clearly define the boundaries between mediation and interpretation does not mean that, as they are closely-related practices, their experiences cannot be mutually beneficial. Nor does it mean that, within the same assignment, a professional does not have to act as an interpreter at times and as a mediator at others. In our view, the awareness of professionals about the role they play at any particular time and the correct integration of the two roles should come from training. Training in intercultural mediation should emphasise the idea that the interpreter does not interpret words but meaning, and that bilingual knowledge is not sufficient to be a good interpreter, that in the interaction the interpreter often cannot be invisible and should give attention to the importance of mastering particular techniques that facilitate the interpreter's work. In this sense, interpreting is not an easy task, since it is both essential and difficult to strike the right balance between, on the one hand, the need for independence of the parties who have to communicate freely despite the language and cultural barriers and, on the other, the need for the individual facilitating communication to intervene in certain circumstances to help the parties effectively overcome these barriers. For its part, the training of interpreters must be based on the idea that linguistic competence is insufficient. It must ensure that interpreting includes mediation, tackles the question of how cultural references are clarified, avoids generalisations and promotes interaction between the parties as well as nonintrusive strategies of empathy, to foster the parties' confidence in the communication setting.

\section{REFERENCES}

Angelelli, C. 2004. Medical Interpreting and Crosscultural Communication. Cambridge: Cambridge University Press. 
Antonin, M. 2009. La Mediación Intercultural en el Sistema de salud de Cataluña. Phd dissertation. Universitat Rovira i Virgili. Retrieved from: http://www.tesisenred.net/handle/10803/8442. Last retrieval: $20^{\text {th }}$ June 2016.

Baraldi, C. \& Gavioli, L. 2007. Dialogue Interpreting as Intercultural Mediation. An Analysis in Healthcare Multicultural Settings. In: Baraldi, C. \& Gavioli, L. (eds.). Dialogue and Culture. Amsterdam-Philadelphia: John Benjamins. 297-326.

Beltran-Avery, M. 2001. The Role of the Health Care Interpreter: An Evolving Dialogue. Department of Health and Human Services Office of Minority Health. Retrieved from: http://www.ncihc.org. Last retrieval: $20^{\text {th }}$ June 2016.

Bermudez, K., Garcia de Castro, R., Garcia Gonzalez-Gordon, H., Lahib, A.,Pomares, F., Prats, G., et al. 2002. Mediacion Intercultural. Una propuesta para la formación. Madrid: AEP Desenvolupament Comunitari y Andalucia Acoge.

Bolden; G.B., 2000. Toward Understanding Practices of Medical Interpreting: Interpreters Involvement in History Taking. Discourse Studies. 2 (4). 387-419.

Burdeus, N. 2015. La interpretación en los servicios públicos en el ámbito sanitario. Estudio comparativo de las ciudades de Barcelona y Montreal. Phd.Dissertation. Departamento de Traducción e Interpretación y Estudios de Ásia Oriental. Universitat Autònoma de Barcelona. Retrieved from: http://www.tdx.cat/handle/10803/310427. Last retrieval: $20^{\text {th }}$ June 2016.

Cohen-Emerique, M. 1997. La négotiation-médiation, phase essentielle de l'intégration des migrants. Hommes \& migrations 1208. 9-23.

Davidson, B. (2000). The Interpreter as Institutional Gatekeeper: the Social-linguistic Role of the Interpreters in the Spanish-English Medical Discourse. Journal of Sociolinguistics. 4 (3). 379-405.

Davitti, E. 2013. Dialogue Interpreting as Intercultural Mediation. Interpreter's use of upgrading moves in parent-teacher meetings. Interpreting. 15:2. 168-199.

Fayman, S. 2000. L'expérience de la médiation sociale et culturelle: etat des lieux dans quelques departement. Paris: Femmes Interassociations; InterService Migrants. FIA/ISM.

Generalitat de Catalunya. 2005. Pla de Ciutadania i Immigració 2005-2008. Secretaria per a la Immigració.

http://ibdigital.uib.es/greenstone/collect/portal_social/import/gencat/gencat0142.pdf. Last retrieval: $20^{\text {th }}$ June 2016 .

Giménez, C. 1997. La naturaleza de la mediación intercultural. Revista Migraciones. 2. 125159.

Hernandez, S. 2006. Sociedades y Conflicto II: El papel de la acción mediadora en la intevención social con poblacion inmigrante. In: J. A. Guerrero Villalba (eds.), Estudios sobre la Mediación Intercultural. Almería: Editorial Universidad de Almería. 93-106.

Lizana, T. (2012). Developing a Migrant Health Policy for Catalonia. In: David Ingleby, D.; Chiarenza, A.; Devillés, W and Korsioni, J. (eds.). Inequalities in Health Care for Migrants and Ethnic Minorities. Antwerpen: Garant. 82-97.

Perez Crespo, M. J. 2005. Mediacion Intercultural. El trabajo con familias de inmigrantes: de la mediacion social intercultural a la mediacion familiar en el espacio comunitario. In F. Romero Navarro (ed.). La Mediación. Una visión Plural. Las Palmas de Gran Canaria: Consejería de Presidencia y Justicia. Viceconsejería de Justicia y Seguridad. Gobierno de Canarias. 251-265. 
Pöchhacker, F. 2008. Interpreting as Mediation. In: Valero-Garcés, C. \& Martin, A. (eds.). Crossing Borders in Community Interpreting. Definitions and Dilemmas. AmsterdamPhiladelphia: John Benjamins. 9-26.

Pöllabauer, S. 2004. Interpreting in asylum hearings: issues of role, responsibility and power. Interpreting. 6,2. 143-180.

Roberts, R. 1997. Community interpreting today and tomorrow. In: S. Carr, R.Roberts, A. Dufour \& D. Steyn (eds.). The critical link: Interpreters in the community. Amsterdam: John Benjamins Publishing Company. 7-26.

Roy, C. (2000). Interpreting as a discourse process. Oxford: Oxford University Press.

Verrept, H. (2004). Mediación intercultural en la atención sanitaria belga. Quaderns CAPS, 32 , 31-39.

Wadensjö, C. 1998. Interpreting as Interaction. London: Longman. 